detected, or the locus identified (usually a fortuitous event). A major gene can only be exploited if different phenotypes or genotypes can be identified, and if performance data for all relevant economic traits are available on all genotypes. Breeding strategies to make best use of the gene can then be evaluated, and compared with progress by conventional selection methods.

\title{
HALOTHANEMPFINDLICHKEIT UND BEZIEHUNGEN ZUR FLEISCHLEISTUNG VON DEN VATERRASSEN PIÉTRAIN UND BELGISCHE LANDRASSE
}

\section{L. SÖNNICHSEN, J. CLAUS und E. KALIM}

Institut f. Tierzucht und Tierhaltung der Christian-Albrechts-Universität zu Kiel, D-23oo Kiel

Der Halothantest wurde bisher an einem Gesamtmaterial von 715 weiblichen Reinzuchttieren der Mastprüfungsanstalt Achterwehr durchgefiihrt.

Der Anteil Hal. $(+)$-Tiere (Reaktionsstufe $4+5$ ) liegt bei 87.2 p. Ico in der Herdbuchpopulation Piétrain und bei 80.2 p. 100 in der Belgischen Landrasse. Diese Tiere haben eine signifikant bessere Handelsklasseneinstufung, eine größere Fleischfläche, ein besseres Fleisch : Fett-Verhältnis und einen höheren $\log$. CK-Wert als die Tiere mit der Halothan-Reaktion $\mathbf{I}+2$. Bei direkten Kriterien der Streßanfälligkeit (Göfo-Wert, Mast- und Transportverluste) bestebt keine Beziehung zur Halothan-Reaktion.

Insgesamt betrachtet haben sich vergleichsweise geringe Leistungsunterschiede zwischen Hal. (+)- und Hal. (-)-Tieren ergeben.

Im Hinblick auf die Frage des genetischen Modells der Halothanreaktion ist zu beonachten, daß die Leistungsunterschiede zwischen den Reaktionsstufen I und 5 zumeist höher ausfielen als zwischen den Reaktionsstufen 2 und 4 .

Das bisherige Datenmaterial 1äßt unseres Erachtens nach keine endgültige Aussage über die Eignung des Halothan-Tests zur Reduzierung der Streßanfälligkeit in den untersuchten Vaterpopulationen $\mathrm{zu}$.

PHENOTYPIC CORRELATION AMONG FATTENING PERFORMANCES AND MEAT QUAITY OF HALOTHANE POSITIVE, AND NEGATIVE KA-HYB HYBRID SWINE POPULATIONS

\section{G. KOVACH}

\author{
Agricultural College of Kaposvar, Hugary
}

The determination of stress-sensitivity of swine have been conducted since 1978 on malelines belonging to the hybrid combinations of KA-HYB production system. According to our breeding program the selection on carcass traits are mainly carried out in father-lines. Therefore it is of great importance to analyse comprehensively the possible consequences of the selectional work.

The conclusions drawn from the results the following:

I. The coefficients of correlation between carcass traits and meat quality were low in both halothane positive and negative pigs.

2. In spite of the low valus and non significance of the correlation coefficients the tendency that asserts itself in the difference between halothane positive and negative groups, is remarkable. The correlations of the traits investigated were ten times as close in the stress-susceptible population than in the stress-resistant group.

3. As a consequence of the selection intended for the further improvement of daily gain of weight and rate of high priced cuts, the meat quality of the halothane positive population presumably will decrease, while in the halothane negative population the meat quality deterioration may not take place. 